\title{
An Epstein-Barr Virus-Negative B Lymphoma Cell Line (THP-2) from a Burkitt's Lymphoma of a Japanese Patient
}

\author{
Shigeru Tsuchiya, Yoshiko Yamaguchi, Yasuko \\ Kobayashi, * Masayoshi Minegishi, Masue Imaizumi, \\ Hiroshi Suzuki, Tasuke Konno and Keiya Tada \\ Department of Pediatrics and *Second Department of Anatomy, \\ Tohoku University School of Medicine, Sendai 980
}

Tsuchiya, S., Yamaguchi, Y., Kobayashi, Y., Minegishi, M., Imaizumi, M., Suzuki, H., Konno, T. and Tada, K. An Epstein-Barr Virus-Negative B Lymphoma Cell Line (THP-2) from a Burkitt's Lymphoma of a Japanese Patient. Tohoku J. exp. Med., 1983, 140 (4), 429-434—An Esptein-Barr virus-negative lymphoma cell line, THP-2, was established from a Burkitt's lymphoma taken from a Japanese patient. THP-2 cells grew in single cell suspension with a doubling time of $24 \mathrm{hr}$; the cells carried surface-bound $\mu-\lambda$ immunoglobulins and formed rosettes with IgG antibody-coated ox erythrocytes. THP-2 cells expressed B1, common acute lymphoblastic leukemia (ALL) (J5) and Ia-like antigens of their surface as defined by monoclonal antibodies. Epstein-Barr virus-associated nuclear antigen (EBNA) was not detected. The cell line THP-2 has been maintained for over 5 years. Among the markers examined, only common ALL antigen has been present on the cell surface of THP-2 for these 5 years. —— B cell line; Burkitt's lymphoma

Establishment of permanent cell lines derived from patients with leukemia or lymphoma has provided useful tools for studies of malignant hematopoietic cells. Such studies have brought important information concerning differentiation sequences of cells in lymphatic series, the origins of leukemia-lymphoma, or precise mechanisms of the differentiation of myeloid cells (Rovera et al. 1980; Minowada et al. 1981; Magrath 1981; Tsuchiya et al. 1982)

The present paper describes the establishment of a new EBNA negative Burkitt's lymphoma cell line (THP-2) with B cell properties and its marker profile.

\section{Materials and Methods}

Case report

A ten-year-old boy who had had a large mass anterior to the sacrum for 5 months was admitted to the Tohoku University Hospital in July 1977. The diagnosis of Burkitt's lymphoma had already been made by biopsy findings of the tumor, showing infiltration of poorly differentiated malignant lymphoma cells with a typical "starry sky' pattern. On his admission the patient was severely ill and the peripheral blood picture

Received for publication, January 24, 1982. 


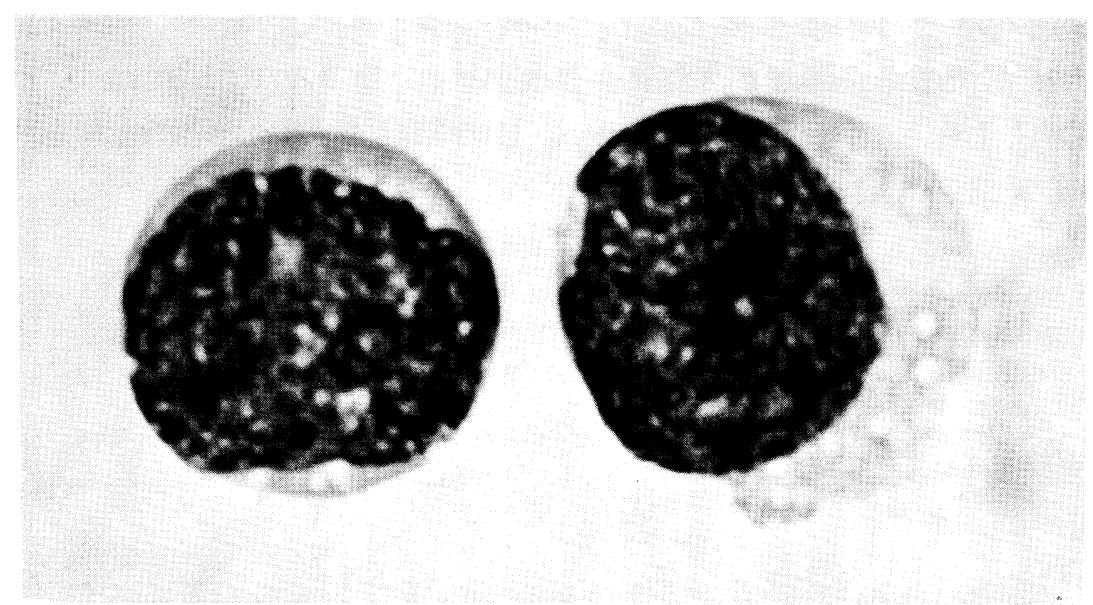

Fig. 1. Wright-Giemsa stain of THP-2 cells.

revealed $18 \%$ of lymphoblasts indicating leukemic transformation of the malignant lymphoma. The patient died of sepsis and intestinal bleeding in August 1977 without any remission despite chemotherapy.

\section{Cell cultures}

Lymphoblasts from the peripheral blood isolated by Ficoll-Isopaque gradient centrifugation were distributed on a Microplate (Falcon, No. 3040, Oxnard, Calif.) at a density of $6 \times 10^{5}$ per $0.2 \mathrm{ml}$ per well in RPMI-1640 medium containing $20 \%$ fetal calf serum and kanamycin. They were cultured at $37^{\circ} \mathrm{C}$ in an atmosphere of $5 \% \mathrm{CO}_{2}$ in air. The medium was changed twice a week. After being established, the cell line, THP-2, was maintained in 8-ml cultures in glass-stoppered plaque bottles.

\section{Morphological studies}

Coverslip smears of the cultured cells were stained with Wright-Giemsa solution for light microscopy. THP-2 was prepared for transmission electron microscopy (TEM) and scanning electron microscopy (SEM) as described previously (Tsuchiya et al. 1982).

TABLE 1. Marker profiles of THP-2

\begin{tabular}{lcccccc}
\hline \multirow{2}{*}{$\begin{array}{c}\text { Period of in } \\
\text { vitro culture }\end{array}$} & \multicolumn{6}{c}{ Surface immunoglobulin positive cells $(\%)$} \\
\cline { 2 - 7 } & $\mu$ & $\delta$ & $\gamma$ & $\boldsymbol{c}$ & $\kappa$ & $\lambda$ \\
\hline 0* & ND & ND & ND & ND & ND & ND \\
2 months & 97.6 & 0 & 0 & 0 & 0 & 98.2 \\
6 months & 98.5 & 0 & 0 & 0 & 0 & 98.2 \\
1 year & 96.9 & 0 & 0 & 0 & 0 & 99.2 \\
2 years & 98.8 & 0 & 0 & 0 & 0 & 98.3 \\
3 years & 96.8 & 0 & 0 & 0 & 0 & 97.2 \\
5 years & 0 & 0 & 0 & 0 & 0 & 0 \\
\hline
\end{tabular}

* Peripheral lymphocytes before cultivation.

Rosette formation with sheep erythroycte (EN), with ox eryth$\mathrm{EAC}^{\mathrm{mo}}$ ). TdT, terminal deoxynucleotidyl transferase; ND, not de- 


\section{Characterization of cell-surface antigens}

The Fc receptor for IgG (EAox), receptors for complements, C3b (human serum) and C3d (mouse serum) (EAChu and $\mathrm{EAC}^{\mathrm{mo}}$, respectively) and spontaneous rosette formation with sheep erythrocytes (EN) were examined as described previously (Tsuchiya et al. 1980). Cell-surface immunoglobulins and cytoplasmic immunoglobulins were detected by direct immunofluorescence. Common ALL (J5) antigen, Ia-like antigen, B1 antigen, and T3, T4, T6, T8 antigens were detected by indirect immunofluorescence with respective monoclonal antibodies (Reinherz and Schlossman 1980; Ritz et al. 1980; Stashenko et al. 1980). Monoclonal antibodies used were purchased from Coulter Corporation (Hialeah, Fla.) and Ortho Pharmaceutical Corporation (Raritan, NJ). Terminal deoxynucleotidyl transferase (TdT) was determined by indirect immunofluorescence using a terminal transferase assay kit (Bethesda Research Lab., Inc., Gaithersburg, MD). Detection of EBNA was done by the method of Reedman and Klein (1973).

\section{Plating efficiency}

Colony formation in semi-solid agar (SeaPlaque agarose, FMC Corpor., Rockland, MD) without feeder cells was performed as described previously (Tsuchiya et al. 1980).

\section{Results}

\section{Establishment of the cell line (THP-2) and morphological features}

Forty-two days after the start of in vitro culture, the proliferating cells were transferred to $8-\mathrm{ml}$ cultures in stopped plaque bottles. The cells grew in single cell suspension, occassionally forming loose clumps of less than 10 cells, with a doubling time of $24 \mathrm{hr}$. The cells appeared uniform and round in shape, with diameter of 8 to $10 \mu \mathrm{m}$ and had large, irregular and indented nuclei containing prominent nucleoli, and basophilic cytoplasm with a few vacuoles. SEM revealed many microvilli on the cell surface (Fig. 2). TEM findings showed many small vesicles and free ribosomes in the cytoplasm (Fig. 3). Karyotype analysis of the THP-2 cells after one-year culture revealed that almost all the cells had a diploid (46, XY) chromosome number.

\section{Marker profile}

Multiple markers of THP-2 cells were analyzed six times from two months to

cells at various times after cultivation

\begin{tabular}{|c|c|c|c|c|c|c|c|}
\hline \multicolumn{4}{|c|}{ Rosette formation with (\%) } & \multicolumn{3}{|c|}{$\begin{array}{c}\text { Reactivity with } \\
\text { monoclonal antibody (\%) }\end{array}$} & \multirow{2}{*}{$\begin{array}{c}\text { TdT } \\
\text { positive } \\
\text { cells (\%) }\end{array}$} \\
\hline EAox & $\mathrm{EAC}^{\mathrm{h} u}$ & $\mathrm{EAC}^{\mathrm{mo}}$ & EN & B1 & $\mathrm{Ia}$ & J5 & \\
\hline 53 & 8 & 7 & 18 & ND & ND & ND & ND \\
\hline 81.3 & 0.1 & 0.1 & 0 & ND & ND & ND & ND \\
\hline 60.6 & 0.2 & 1.0 & 0 & ND & ND & ND & ND \\
\hline 24.8 & 0 & 0 & 0 & ND & ND & ND & ND \\
\hline 0 & 0 & 0 & 0 & 96.7 & 98.2 & 98.8 & 0 \\
\hline 0 & 0 & 0 & 0 & 97.5 & 97.2 & 98.1 & 0 \\
\hline 0 & 0 & 0 & 0 & 0 & 0 & 23.2 & 0 \\
\hline
\end{tabular}

rocyte-IgG complex (EAox), with ox erythrocyte-IgM-complement (EAChu, termined. 


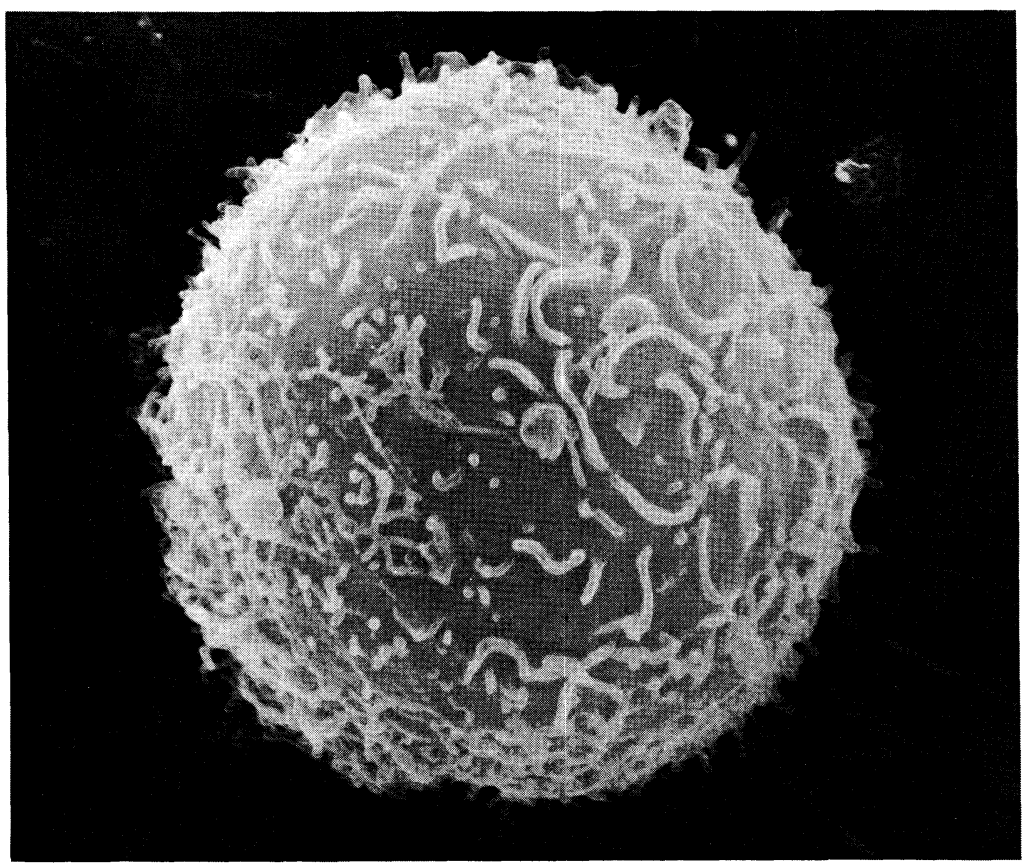

Fig. 2. Scanning electron microscopic appearance of a THP-2 cell. Note a number of microvilli on the cell surface. $\times \mathbf{8 , 4 0 0}$.

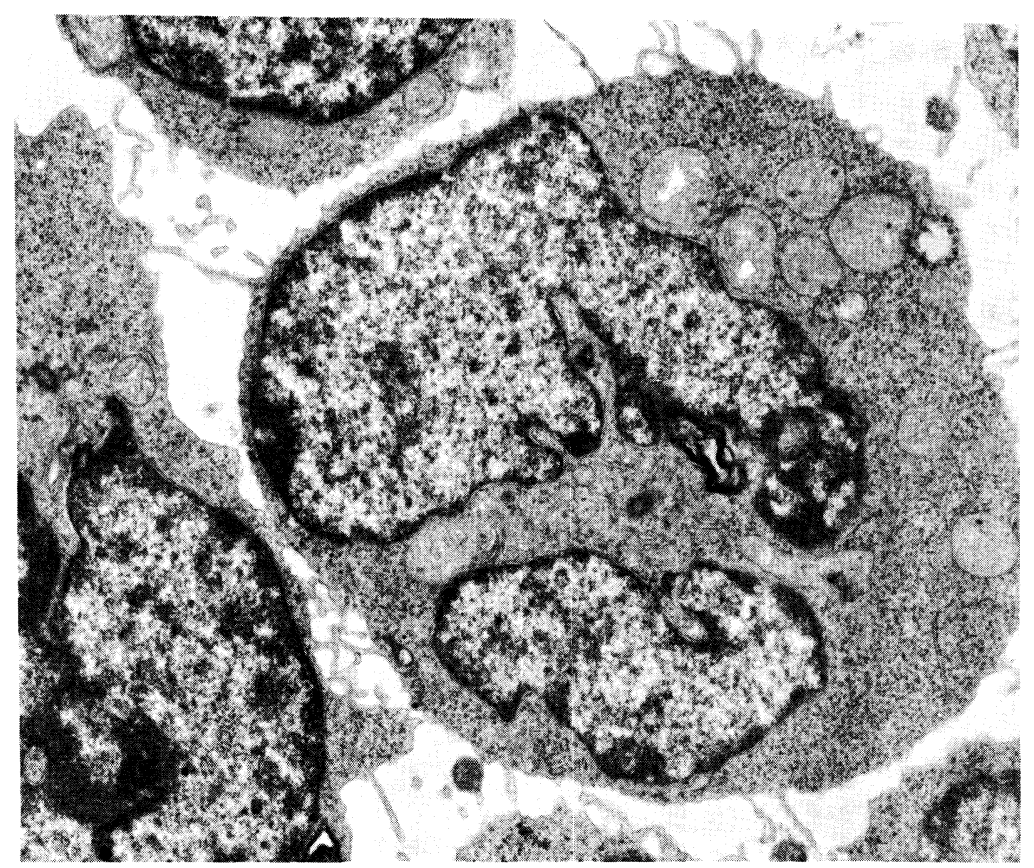

Fig. 3. Ultrastructural appearance of a THP-2 cell. Note an indented nucleus and a number of small vesicle and free ribosomes. $\times 7,500$. 
five years after cultivation (Table 1). At the first examination $81 \%$ of the cells had Fe receptors, while only $0.1 \%$ were positive for complement receptors. However, the number of $\mathrm{Fc}$ receptor ${ }^{+}$cells decreased with the time of cultivation and were not detected after two years of cultivation. There were no $\mathrm{EN}^{+}$cells. Immunofluorescent studies showed that THP-2 cells bore $\mu-\lambda$ immunoglobulin on their surface and reacted with the monoclonal antibodies against B1, Ia-like and common ALL (J5) antigens. However, such surface markers of cells as Fc receptor, IgM, B1 antigen and Ia-like antigen were not detected when examined after 5 years of cultivation, while common ALL (J5) antigen was still present in $23 \%$ of the cells. Cytoplasmic immunoglobulins, TdT and EBNA were not detected by immunofluorescence at any time during culture. Monoclonal antibodies against $\mathrm{T}$ cells and their subsets (OKT3, OKT4, OKT6, OT8) did not react with THP-2 cells.

\section{Plating efficiency}

Cultured THP-2 cells formed colonies in $0.3 \%$ semi-solid agar with a plating efficiency of $2.3 \% 28$ days after the seeding of the cells in the plate. The cells of each colony were transformed into a suspension culture in order for cloned cell lines of THP-2 to be obtained. Ten clones of THP-2 were obtained growing in a suspension culture and bearing the same surface antigen profiles as shown in the parent THP-2 cells. There were several unsuccessful attempts to transplant the THP-2 cells into the subcutaneous tissue of nude mice.

\section{Discussion}

We have established an EBNA negative Burkitt's lymphoma cell line from a Japanese patient with Burkitt's lymphoma. Two other EBNA negative cell lines derived from Burkitt's lymphoma taken from Japanese patients have been established (Miyoshi et al. 1977; Hayashi et al. 1980). These three lines established in Japan have all been grown in single cell suspensions and bore surface immunoglobulins. In addition, THP-2 cells were positive for Ia-like antigen, common ALL antigen (J5) and human B cell specific antigen (B1) on their surface. B1 antigen, known to be a unique B cell surface differentiation antigen, was positive in all B cell lymphoma cells reported (Nadler et al. 1981). On the other hand, the expression of common ALL antigen, which permits classification of B cell lines, has not always occurred on the Burkitt's lymphoma cells; these were common ALL positive "B-blast I" and common ALL negative "B-blast II", which are considered to be in different differentiation stages (Minowada et al. 1981). In the sense of the stage of differentiation, the marker profile of THP-2 cells coincided with that of B-blast I. In year-5 culture surface markers of THP-2 cells, present for 3 years such as IgM, B1 antigen and Ia-like antigen were not detected, while the cells had common ALL antigen on their surface. This phenotypic alteration with time may suggest that THP-2 cells became less differentiated along the B cell lineage during long term culture, though the significance of this is unknown at present. 


\section{Acknowledgment}

This work was supported by grants from the Ministry of Education, Science and Culture and the Ministry of Health and Welfare, Japan.

\section{References}

1) Hayashi, Y., Matsumura, Y., Nishihira, T., Watanabe, I., Ohi, R., Kasai, M., Kumagai, K. \& Kamada, N. (1980) Burkitt's lymphoma cell line bearing surface IgA and negative for nuclear antigen of Epstein-Barr virus (EBNA). Jap. J. exp. Med., 50, 423-434.

2) Magrath, I.T. (1981) Lymphocyte differentiation: An essential basis for the comprehension of lymphoid neoplasia. J. nat. Cancer Inst., 67, 501-513.

3) Minowada, J., Koshiba, H., Sagawa, K., Kubonishi, I., Lok, M.S., Tatsumi, E., Han, T., Srivastava, B.I.S. \& Ohnuma, T. (1981) Marker profiles of human leukemia and lymphoma cell lines. J. Cancer Res. clin. Oncol., 101, 91-100.

4) Miyoshi, I., Hiraki, S., Kubonishi, I., Matsuda, Y., Kishimoto, H., Nakayama, T., Tanaka, T., Masuji, H. \& Kimura, I. (1977) Establishment of an Epstein-Barr virusnegative B-cell lymphoma line from a Japanese Burkitt's lymphoma and its serial passage in hamsters. Cancer, 40, 2999-3003.

5) Nadler, L.M., Ritz, J., Hardy, R., Pesando, J.M., Schlossman, S.F. \& Stashenko, P. (1981) A unique cell surface antigen identifying lymphoid malignancies of $\mathrm{B}$ cell origin. J. clin. Invest., 67, 134-140.

6) Reedman, B.M. \& Klein, G. (1973) Cellular localization of an Epstein-Barr virus (EBV)associated complement-fixing antigen in producer and non-producer lymphoblastoid cell lines. Int. J. Cancer, 11, 499-520.

7) Reinherz, E.L. \& Schlossman, S.F. (1980) The differentiation and function of human T lymphocytes: A review. Cell, 19, 821-827.

8) Ritz, J., Pesando, J.M., Notis-McConarty, J., Lazarus, H. \& Schlossman, S.F. (1980) A monoclonal antibody to human acute lymphoblastic leukemia antigen. Nature, 283, 583-585.

9) Rovera, G., Olashaw, N. \& Meo, P. (1980) Terminal differentiation in human promyelocytic leukemia cells in the absence of DNA synthesis. Nature, 284, 69-70.

10) Stashenko, P., Madler, L.M., Hardy, R. \& Schlossman, S.F. (1980) Characterization of a human B lymphocyte specific antigen. J. Immunol., 125, 1678-1685.

11) Tsuchiya, S., Yamabe, M., Yamaguchi, Y., Kobayashi, Y., Konno, T. \& Tada, K. (1980) Establishment and characterization of a human acute monocytic leukemia cell line (THP-1). Int. J. Cancer, 26, 171-176.

12) Tsuchiya, S., Kobayashi, Y., Goto, Y., Okumura, H., Nakae, S., Konno, T. \& Tada, K. (1982) Induction of maturation in cultured human monocytic leukemia cells by a phorbol diester. Cancer Res., 42, 1520-1536. 